\title{
Jinan City Land Without Water Port Construction Model
}

\author{
Zhang Shuyin ${ }^{1, *}$, Guo Ruiqi ${ }^{1}$, Wu Yuxuan ${ }^{1}$, Wang Kunmin ${ }^{1}$, Han Yudong $^{1}$ and Zhang Xiaobai ${ }^{1}$ \\ ${ }^{1}$ Logistics Department, Shandong Jiaotong University, Jinan, Shandong Province, 250357, China
}

\begin{abstract}
With the global economic integration and the continuous development of the logistics industry, multi-directional transport in the international position is becoming more and more important, the port is the carrier of the development of multi-vehicle transport. The competition of various countries is no longer the competition of the previous infrastructure and operational capacity, and the construction of a waterless port in the inland will become an effective measure for the sustainable development of Jinan. Taking the development of multi-mode transportation in Jinan as the background, this paper analyzes the strategic environment for the development of inland waterless port in Jinan city and the construction mode of inland waterless port in Jinan city by introducing the multi-mode transportation in Jinan area.
\end{abstract}

\section{Introduction}

Dryless ports are also called "inland ports". Inland cities lack the conditions of river transportation and sea transportation. The construction of dryless ports can make up for the shortage of port quarantine and service in land cities, promote the export of inland enterprises, and expand the service function of inland cities. The waterless port is mainly built in the core of the road, railway and air transportation network to facilitate the loading and unloading, gathering and transportation of goods. According to the international transportation agreement and treaty, the establishment of comprehensive land ports open to the outside world is the basis for the establishment of waterless ports. The service departments of customs, quality inspection and comprehensive quarantine as well as the branch offices of cargo agents, shipping agents and shipping companies are set up in the dry port, which is convenient for the consignor to sign and issue the documents as well as the consignee to receive the documents. Waterless port is the core of land and water combined transportation, providing one-stop service for foreign trade, and is an important institution to promote the export of foreign trade in inland cities. At present, the waterless port can be divided into three levels: the first level is the comprehensive protected waterless port, which has the functions of visa, quarantine and bonded; Level 2 is a combined transport dry port with basic service function of dry port. Level 3 is a highway waterless port with less scale and function. It mainly provides one-stop office for import and export enterprises and international logistics enterprises to operate international logistics documents and international container transport services. The significance of the establishment of waterless port is to promote the development of foreign trade and foreign development degree of land cities, so as to promote the economic development of inland cities.

\section{Analysis on Strategic Environment of Developing Waterless Port in Jinan}

\subsection{SWOT Analysis of the Basic Steps}

The basic steps of the SWOT analysis method are:

(1) The internal advantages and disadvantages of an enterprise can be analyzed in terms of its goals or competitors, but they must be viewed from the perspective of customers.

(2) Analyzing the external opportunities and threats facing the enterprise. These opportunities and threats may arise from changes in external environmental factors, changes in competitors' advantages, or both.

(3) Match external opportunities and threats with internal strengths and weaknesses to form a feasible strategy.

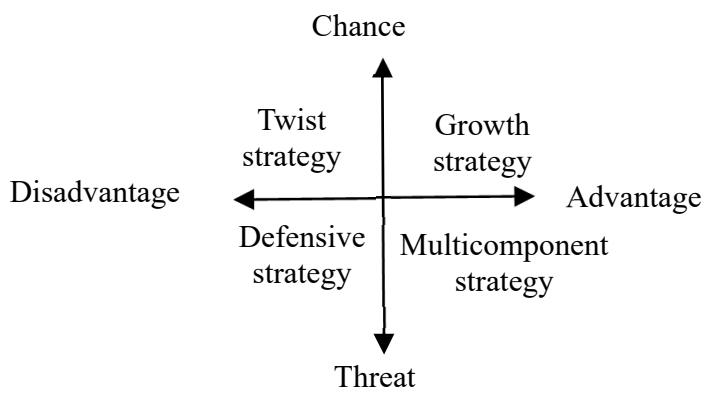

Figure 1. Diagram of SWOT strategy analysis

\subsection{Analysis of Opportunities}

The national government advocates the integration of enterprises, the key to the realization of enterprise integration lies in the improvement of infrastructure, and 
perfecting the logistics system is an important part of regional integration infrastructure construction, inland waterless port projects as an important part of the logistics system, will inevitably get government funds, policies and other support. The establishment of waterless port can greatly reduce the cost of container logistics in inland areas, effectively alleviate the congestion of ports, and improve the efficiency of international container multitransport. Waterless port meets the needs of container international logistics in inland areas, making it the best choice for effective handling of international container logistics. Through the establishment of a direct customs clearance platform between coastal ports and inland areas, the customs conditions can be facilitated for import and export enterprises in inland areas, while the construction of inland channels should be achieved by inland carriers represented by waterless ports.

\subsection{Analysis of Threats}

Modern integrated logistics service puts forward higher requirements for port service level. In addition to having international shipping market, strong hinterland economy, rich container logistics and distribution system, the establishment of international shipping center must also have good service system of maritime frontier inspection, health inspection, etc. At present, the comprehensive service level of Jinan is still low, and the progress of infrastructure construction is slow, which is difficult to meet the needs of the rapid development of modern logistics services. The development of waterless ports involves many stakeholders, such as local governments, ports, railways, customs, inspection and Quarantine Bureau, etc., and a good business environment for the development of waterless ports needs cooperation and cooperation from all parties. However, in order to maximize their own interests, regardless of long-term interests, enterprises adopt a non-cooperative and noncooperative attitude towards the construction of waterless ports, which makes it quite difficult for all parties to coordinate.

\subsection{Analysis of the Advantages}

Jinan is located in the central and western parts of Shandong Province, is the intersection of the BeijingShanghai Railway and the Jiaozhou-Jinan Railway, with great potential for economic development. North, northwest and northeast China are rich in resources, metallurgy, petrochemicals and machinery manufacturing industries are very developed, agricultural base is strong. In the future, the region will give full play to its resource advantages, vigorously develop heavy chemical industries such as metallurgy and petrochemicals, and develop modern equipment manufacturing industries represented by transportation equipment, machinery and heavy equipment, electrical appliances and equipment. Industry, represented by high-quality steel, is an important raw material and industrial production base, while accelerating the development of high-tech industries research.

\subsection{Analysis of the Disadvantages}

Jinan traffic congestion is serious, transport efficiency is affected, highway network has not yet been formed, the external highway channel is less, transport capacity is insufficient, highway hub construction is seriously lagging behind, small scale, scattered layout, with other modes of transport and urban traffic links are not smooth, which not only affects the efficiency of the transport of goods without water port, but also greatly increases the transport cost of goods when transporting goods in large quantities. The development of waterless port, in addition to the need to have perfect hardware facilities, but also need to constantly improve the service and management system, including can provide first-class services in customs, border inspection, health inspection, plant inspection and port supervision and other port inspection and inspection institutions.

\subsection{Comprehensive Analysis}

Before a port can implement a development strategy, it is necessary to clarify the current external environment and the internal environment in order to be targeted. Therefore, based on the previous analysis of the opportunities and threats of the external environment and the advantages and disadvantages of Jinan Port, the SWOT analysis matrix of the development environment of Jinan Port without water port is derived, such as Table 1.

Table 1. Jinan construction waterless port SWOT analysis matrix

\begin{tabular}{|l|l|l|}
\hline \multirow{5}{*}{$\begin{array}{l}\text { The internal } \\
\text { environment }\end{array}$} & $\begin{array}{l}\text { Advantage } \\
\text { advantage is } \\
\text { outstanding } \\
\text { 2.hinterland socio- } \\
\text { economic potential is } \\
\text { huge }\end{array}$ & $\begin{array}{l}\text { Disadvantage } \\
\text { infrastructure is } \\
\text { not perfect } \\
\text { 2.the } \\
\text { international } \\
\text { shipping center's } \\
\text { service and } \\
\text { management } \\
\text { system is not } \\
\text { perfect }\end{array}$ \\
& $\begin{array}{l}\text { 3.lack of high- } \\
\text { quality logistics } \\
\text { management } \\
\text { personnel }\end{array}$ \\
\hline \multirow{5}{*}{$\begin{array}{l}\text { The external } \\
\text { environment }\end{array}$} & $\begin{array}{l}\text { Threat } \\
\text { international container } \\
\text { transport } \\
\text { 3.the port's main } \\
\text { hinterland of the rapid } \\
\text { development of } \\
\text { foreign trade }\end{array}$ & $\begin{array}{l}\text { 1. modern } \\
\text { integrated } \\
\text { logistics services } \\
\text { on the port } \\
\text { service level } \\
\text { requirements are } \\
\text { strict } \\
\text { 2.Infrastructure } \\
\text { construction in } \\
\text { inland areas is } \\
\text { slow }\end{array}$ \\
\cline { 2 - 3 } & $\begin{array}{l}\text { 3. the } \\
\text { coordination of }\end{array}$ \\
\hline
\end{tabular}




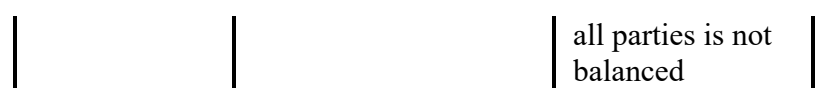

According to. the SWOT analysis of Jinan's development of a waterless port, taking into account the current internal and external environment of the port, four different strategic combinations are formulated from the principles of criticality, feasibility, quantification, consistency, incentive, stability, etc.: SO strategy - longterm strategy; ST strategy - stability strategy; WO strategy - reversive strategy; WT strategy - defensive strategy, as shown in Table 2.

Table 2. Development strategy choices

\begin{tabular}{|c|c|}
\hline $\begin{array}{l}\text { SO Strategy - Long-Term } \\
\text { Strategy }\end{array}$ & $\begin{array}{l}\text { ST Strategy - Stability } \\
\text { Strategy }\end{array}$ \\
\hline $\begin{array}{l}\text { Take advantage of advantages } \\
\text { and opportunities to maintain } \\
\text { the existing business areas, and } \\
\text { continue to make every effort to } \\
\text { expand the scale of operations in } \\
\text { this area, actively expand the } \\
\text { market, the implementation of } \\
\text { growth-oriented business } \\
\text { strategy. } \\
\text { Cons: } \\
\text { disadvantages are not taken into } \\
\text { account. } \\
\text { Strategic characteristics: play to } \\
\text { the advantages, take advantage } \\
\text { of opportunities. }\end{array}$ & $\begin{array}{l}\text { Use your strengths to } \\
\text { avoid threats, maintain } \\
\text { your existing business } \\
\text { and stop expanding in } \\
\text { that area. Use their own } \\
\text { financing capacity to } \\
\text { move into other areas and } \\
\text { implement a diversified } \\
\text { business strategy. }\end{array}$ \\
\hline $\begin{array}{l}\text { WO Strategy }- \text { Reversive } \\
\text { Strategy }\end{array}$ & $\begin{array}{l}\text { WT Strategy - Defensive } \\
\text { Strategy }\end{array}$ \\
\hline $\begin{array}{l}\text { Take advantage of opportunities } \\
\text { to improve internal weaknesses, } \\
\text { diversify and develop core } \\
\text { competency while maintaining, } \\
\text { stabilizing, developing and } \\
\text { enhancing existing areas of } \\
\text { operation. } \\
\text { Pros: Use opportunities and } \\
\text { strengths to avoid threats and } \\
\text { overcome disadvantages. } \\
\text { Strategic characteristics: Take } \\
\text { advantage of opportunities to } \\
\text { overcome weaknesses. }\end{array}$ & $\begin{array}{l}\text { In order to overcome } \\
\text { weaknesses, avoid } \\
\text { threats, abandon existing } \\
\text { business areas, go all out } \\
\text { to other related areas, and } \\
\text { strive to occupy the } \\
\text { technological } \\
\text { commanding heights. } \\
\text { Cons: Give up existing, } \\
\text { potential opportunities } \\
\text { and advantages features: } \\
\text { Strategic weaknesses } \\
\text { Overcome we } \\
\text { and avoid threats }\end{array}$ \\
\hline
\end{tabular}

Through the SWOT analysis conclusion and the above combination table, it can be seen that Jinan has numerous opportunities and accumulated advantages to develop waterless ports at present, so the port should seize the opportunities and choose the expansion and growth development strategy.

\section{Analysis of the Construction Mode of the Waterless Port in Jinan City}

Jinan's waterless port construction model is mainly divided into port-based waterless port, city-based waterless port and port-based waterless port.

\subsection{Analysis of Waterless Harbours Based on Seaports}

A port-based waterless port is a waterless port built jointly by coastal port enterprises with inland areas in order to secure the supply of goods. The most important way to complete customs clearance at a waterless port is through rail and road to coastal ports along the river, and sea transport continues to be achieved. The differentiated positioning and cooperation mechanism with coastal ports is an important part of the development model of waterless ports. Waterless ports should be flexible in choosing seaports according to the type and quantity of goods, so as to achieve the best cost and the greatest benefit. For waterless ports and surrounding areas of unique species, waterless ports can choose to transport such goods experienced, obvious advantages of coastal ports, to establish long-term cooperative relations. While maintaining independence, we should also make diversified use of bonded logistics parks to carry out various forms of business with coastal ports and promote each other. The support of the harbour is the basis for the development of inland waterless port, in the process of inland waterless port development, the port needs to facilitate customs clearance, insurance, logistics planning, report management and advice services, but also need a good docking platform, so that inland waterless port goods through the public rail transport to the port, to provide good container storage, transportation and loading services, transport process as shown in Figure 2. In short, the purpose of setting up a waterless port in the Mainland is to enhance the competitiveness of its business in the Mainland.

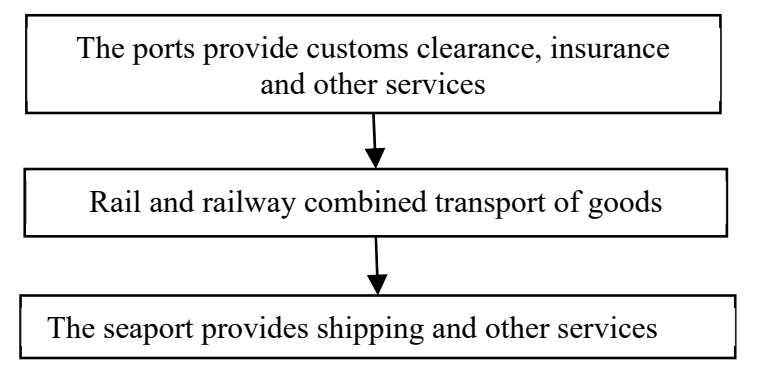

Figure 2. A map of the transport flow of a waterless port based on a seaport

\subsection{City-based Waterless Port Analysis}

A city-based waterless port is a waterless port established in inland areas to develop the local economy. The construction project of inland waterless port requires a large area of land, so it needs the support of government land planning to provide the basis for the project to optimize the site selection. In the process of construction and operation, a large amount of working capital is needed, and if we rely solely on the efforts of Jinan inland port, it will bring great financial pressure. Therefore, in the process of construction and operation, Jinan inland waterless port project can seek the financial support of 
government departments, such as tax concessions, preferential loan interest concessions, seeking government financial subsidies and so on. Inland waterless port should not only promote the economic and foreign trade development of the city, as a central city or hub city in a region, but also promote the industrial and economic development of the surrounding areas. Therefore, in addition to the city's supply, but also to actively explore the channel organization around the relatively underdeveloped areas of the source, make full use of lowcost, high-quality advantages of international trade, through the waterless port to drive the coordinated development of the surrounding areas. At the same time, the construction of waterless port, speed up the improvement of the entire region's transportation network system, to ensure transport channels and transport efficiency.

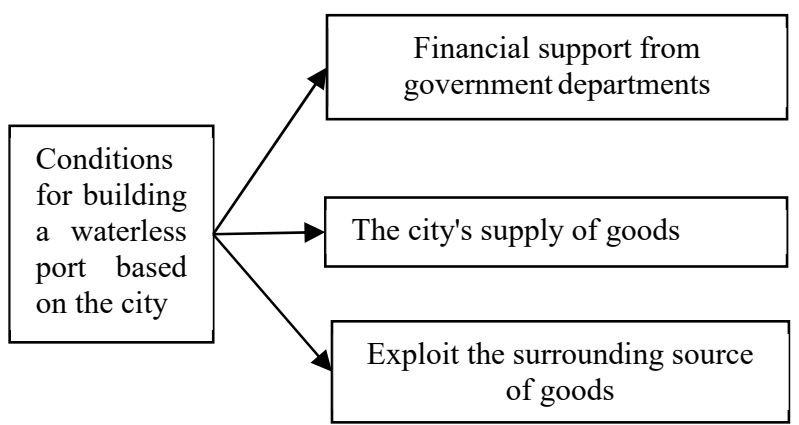

Figure 3. Resources for the construction of a waterless port based on the city

\subsection{Analysis of Waterless Ports Based on Ports}

Waterless port based on port A waterless port jointly established by coastal port enterprises and inland areas for their respective development needs. The newly developed inland port function is utilized to optimize the transportation mode of goods in international trade and select the most appropriate transportation mode. First, the waterless port based on ports can realize the functions of FCL loading and unloading as well as delivery of containers. In the construction and operation of inland waterless ports, railway transportation will become the most important way. Therefore, in terms of the site selection of inland dry ports, it is necessary to first consider placing the dry ports near the railway lines, so that the dry ports have the service functions of whole-line cargo dispatch, container loading and unloading, customs declaration and so on, so as to ensure the logistics circulation of inland dry ports and ports. Second, it can realize the function of direct docking between inland dry port and customs clearance port, that is, Jinan dry port needs the establishment of quarantine, supervision and other service agencies, so as to directly complete the customs declaration and quarantine of goods in the region. Third, it can realize one-to-one and its "door to door" cargo transportation service, and realize the container cargo handover mode under various transportation terms signed in the waterless port. Fourthly, the function of container management can be realized. The logistics unit will transport the containers full of goods to the port and carry the empty containers to the waterless port.

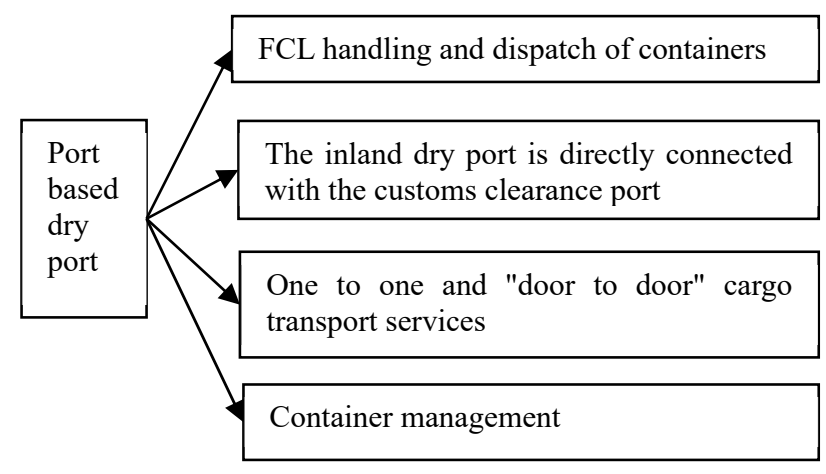

Figure 4. The function of waterless port based on port

\section{Conclusion}

While the global economic integration and the continuous development of logistics industry, it also improves the international status of multi-transport, and the carrier of multi-vehicle development is the port. Jinan's waterless port operation mode suggests the use of market-oriented operation mode and the combination of government and social investment to form a fair, just and open competition order, making full use of all kinds of resources into the field. Jinan city harbor is less, the construction of waterless port in inland areas, and the formation of land and sea transport cargo distribution center, improve Jinan's logistics efficiency, reduce logistics costs.

\section{References}

1. Function Evaluation of Inland Dry Port in Multimodal Transport[J]. Yuan Kebiao. Science and technology of ports. 2020(10)

2. MengXiangru. Transport Histology. Beijing: Peking University Press.2014(3)

3. Study on Optimization of Inland Collection and Distribution of Ports. [D]. Zhang Fengchun. Daliann Maritime University.2015

4. Study on the Development Strategy of Tianjin Port Inland Waterless Port Project.Song Guowei. Daliann Maritime University.2019

5. Study on Site Selection of Waterless Port and Measurement of Spatial Scope of Economic Hinterland [D].Hao Hailin.Yanshan University.2018

6. Discussion on the Construction Condition and Mode of Chongqing Waterless Port [J].Xie Hongli,Wei Jun. Chinese Water Shipping (Second Half).2014(06) 